\title{
Characterization and Genome Sequencing of a Novel Coliphage Isolated from Engineered Escherichia coli
}

\author{
Shu Li Lina Liu Junmin Zhu Lingyun Zou Ming Li Yanguang Cong \\ Xiancai Rao Xiaomei Hu Yingbing Zhou Zhijin Chen Fuquan Hu \\ Department of Microbiology, Third Military Medical University, Chongqing, China
}

\section{Key Words}

Bacteriophages $\cdot$ Coliphage $\cdot$ Engineered E. coli phage $\cdot$

Genome sequencing $\cdot$ Host range

\begin{abstract}
Objectives: To characterize morphological, physicochemical and genomic features of a novel virulent coliphage which was isolated from an engineered Escherichia coli culture and termed engineered E. coli phage (EEP). Methods and Results: Electron microscopy revealed that EEP has an icosahedral head ( $62 \mathrm{~nm}$ in diameter) and a long, flexible tail (138 nm in length). EEP was able to infect all 10 engineered $E$. coli strains kept in our laboratory, showing a strong ability to lyse engineered E. coli. Sequencing of the EEP genome revealed a double-stranded DNA (39.8 kb) with $54.72 \%$ GC content. Fifty-two open reading frames were predicted to be coding sequences, 18 of which were functionally defined and organized in a modular format, which includes modules for DNA replication, DNA packaging, structural proteins and host cell lysis. This phage could not be inactivated at $90^{\circ}$ for $45 \mathrm{~min}$ and was resistant to ethanol and alkali treatment. EEP is assigned to the Siphoviridae family based on its morphological, genomic and physicochemical properties. Conclusions: A novel coliphage was isolated from engineered $E$. coli
\end{abstract}

strains, and its morphological, genomic and physicochemical properties were characterized, which will improve our knowledge of bacteriophage diversity.

Copyright $\odot 2010$ S. Karger AG, Basel

\section{Introduction}

Bacteriophages are the most abundant biological entities on the planet [1] and are not only highly diverse among themselves, but also result in the diversity of other organisms through the horizontal transference of genetic material, such as bacterial virulence genes [2-5]. Bacteriophages have therefore become an excellent model system and an effective biological tool for understanding fundamental biological phenomena. Although there are approximately $10^{31}$ different bacteriophages in the biosphere [6], only about 5,500 have been examined using electron microscopy [7], and only 554 phage genomes have been sequenced to date, even fewer than those of bacteria. Isolation and identification of a novel bacteriophage will therefore provide new data on bacteriophage biodiversity, while sequencing of the bacteriophage genome will improve our understanding of phage and bacterial evolution.

\section{KARGER}

Fax +4161306 1234 E-Mail karger@karger.ch www.karger.com

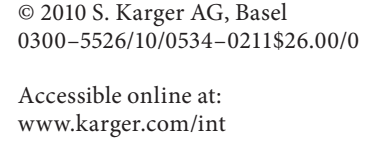

Tel./Fax +86 236875 2240, E-Mail hoofuquan@yahoo.com.cn 
Genetically engineered bacteria are also important tools and materials in the field of molecular biology, and have been extensively used in research and bioprocessing industries. Bacteriophage infection of engineered bacteria could have serious consequences due to its inhibition of the fermentation process. Consequently, the fermentation process may be slowed or completely stopped, thereby reducing the quality of the final products. Among the engineered bacteria, Escherichia coli is the most frequently used. However, there have been few studies on phages of engineered E. coli, except for that of Iida et al. [8], and no engineered $E$. coli phage genome sequence has yet been published, although about 70 Enterobacteria phages have been completely sequenced.

The phage EEP reported here was occasionally found on agar plates of engineered E. coli BL21 (DE3). This phage was able to lyse all 10 tested engineered E. coli strains and demonstrated a potent lytic ability for engineered E. coli. Investigation of the biological traits and whole genome sequence of EEP will lead to a better understanding of this new bacteriophage and devise effective control procedures to alleviate the devastating consequences of its attack in bioprocessing industries and in laboratory environments.

\section{Materials and Methods}

\section{Strains and Phages}

EEP was occasionally isolated during an electroporation experiment in which engineered E. coli strain BL21 (DE3) was used as competent cell. BL21 (DE3) cells were subsequently used as host cells for EEP. Ten genetically engineered E. coli strains, including BL21 (DE3), DH10B, DH5 $\alpha$, JM109, M15, Rosetta, Rosetta-gami, S17-1, S17-1 $\lambda$ pir $^{+}$and TOP10, and E. coli ATCC 35218 were purchased. The susceptibilities of all the strains to EEP were investigated.

\section{Propagation and Purification of Phages}

EEP particles were added to BL21 (DE3) cultures at $0.01 \mathrm{mul}-$ tiplicity of infection and incubated for a further $12-16 \mathrm{~h}$ after infection. Crude phage suspensions were prepared by centrifugation of the cultures $\left(10,000 \mathrm{~g}\right.$ for $15 \mathrm{~min}$ at $\left.4^{\circ}\right)$ to remove the cells and by passing the supernatants through a membrane filter $(0.45-$ $\mu \mathrm{m}$ pore size). This method yielded phage titers as high as $10^{10}$ $10^{11}$ plaque-forming units $(\mathrm{PFU}) / \mathrm{ml}$. Crude phage suspensions were concentrated with $10 \%$ polyethylene glycol 8000 and $1 \mathrm{M}$ $\mathrm{NaCl}$, according to the method of Govind et al. [9]. The precipitate was further purified using $\mathrm{CsCl}$ gradient ultracentrifugation [10, $11]$.

\section{Electron Microscopy}

CsCl-purified EEP suspensions $(20 \mu \mathrm{l})$, at a concentration of $10^{12}-10^{13} \mathrm{PFU} / \mathrm{ml}$, were deposited onto carbon-coated copper grids and allowed to adsorb for $15 \mathrm{~min}$. The phage particles were negatively stained using $2 \%(\mathrm{w} / \mathrm{v})$ potassium phosphotungstate ( $\mathrm{pH} 7.2)$ and examined using a Philips TECNAI 10 electron microscope (Philips, The Netherlands).

One-Step Growth Curve

For one-step growth experiments, a modification of the method of Lu et al. [12] was used, with 15-min adsorption at $37^{\circ}$. Following centrifugation at $13,000 \mathrm{~g}$ for $30 \mathrm{~s}$, the pelleted cells were resuspended in $5 \mathrm{ml}$ preheated Luria-Bertani broth, followed by incubation at $37^{\circ}$. Samples were taken at 10 -min intervals (up to $2 \mathrm{~h}$ ) and immediately titered by PFU counting assay [13]. Experiments were repeated three times with duplicate samples.

Physicochemical Stability of EEP

Resistance of EEP to different temperatures, ethanol levels and $\mathrm{pH}$ values was determined, according to the methods of Capra et al. [14]. All results were expressed as the concentration (PFU/ml) of active viral particles and its $\log _{10}$ plotted against time.

Sodium Dodecyl Sulfate-Polyacrylamide Gel Electrophoresis and N-Terminal Sequencing of Phage Proteins

CsCl-purified EEP samples were mixed with sodium dodecyl sulfate (SDS)-polyacrylamide gel electrophoresis (PAGE) sample buffer and heated in a boiling water bath for $3 \mathrm{~min}$, then electrophoresed in a $12 \%$ SDS polyacrylamide gel. The gel containing the separated protein bands was transferred onto a polyvinylidene fluoride membrane (Millipore, Germany) for sequencing of Nterminal amino acids using an Applied Biosystems Procise 491 protein sequencer (Applied Biosystems, USA; Service Center of Protein Sequencing, Beijing University).

\section{Preparation of Phage DNA}

EDTA was added to the purified phage stock solution at a final concentration of $20 \mathrm{mM}$, proteinase $\mathrm{K}$ at $50 \mathrm{mg} / \mathrm{ml}$, and SDS at $0.5 \%(\mathrm{w} / \mathrm{v})$. The mixture was incubated at $56^{\circ}$ for $1 \mathrm{~h}$, and then purified by phenol extraction and ethanol precipitation. Finally, EEP genomic DNA was stored at $4^{\circ}$ for use.

Genomic Sequencing and Analysis

Purified EEP genomic DNA was sequenced at the Beijing Genomics Institute, using methods described previously [15-17]. Briefly, phage DNA was mechanically sheared and size fractionated by agarose gel electrophoresis. Fragments $1.6-2.0 \mathrm{~kb}$ in size were recovered. The fragments were then digested with mung bean nuclease and ligated to phosphatase-treated vector pUC18/SmaI/BAP. The ligated plasmids were electronically transferred to competent E. coli $\mathrm{DH} 5 \alpha$. The transformed cells were extracted using a Prep 96 plasmid kit and used as DNA sequencing templates. The sequencing work was completed using an Abi Prism ${ }^{\text {TM }} 377$ auto DNA sequencer (Perkin Elmer, USA).

Poor-quality data and vector sequences were removed from the automated sequencing results and the remaining sequences were assembled into contigs using the Phred/Phrap/Consed software package (Genomic Center, Washington University, USA). Open reading frames (ORFs) were analyzed using ORF Finder at the NCBI (http://www.ncbi.nlm.nih.gov/gorf/gorf.html) and putative genes were analyzed using GeneMark.HMM (http://opal. biology.gatech.edu/GeneMark/genemark24.cgi). Nucleotide sequences and protein sequences were scanned for homologues using BLAST (http://blast.ncbi.nlm.nih.gov/Blast.cgi). 


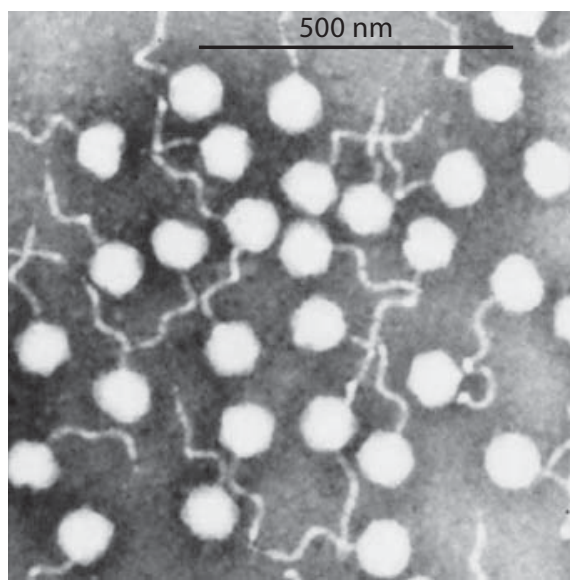

Fig. 1. Electron micrograph of EEP. Purified phage particles were stained with potassium phosphotungstate and observed in a transmission electron microscope. Bar $=500 \mathrm{~nm}$. The phage particle has an icosahedral head (62 $\mathrm{nm}$ in diameter) and a long, flexible tail (138 $\mathrm{nm}$ in length).

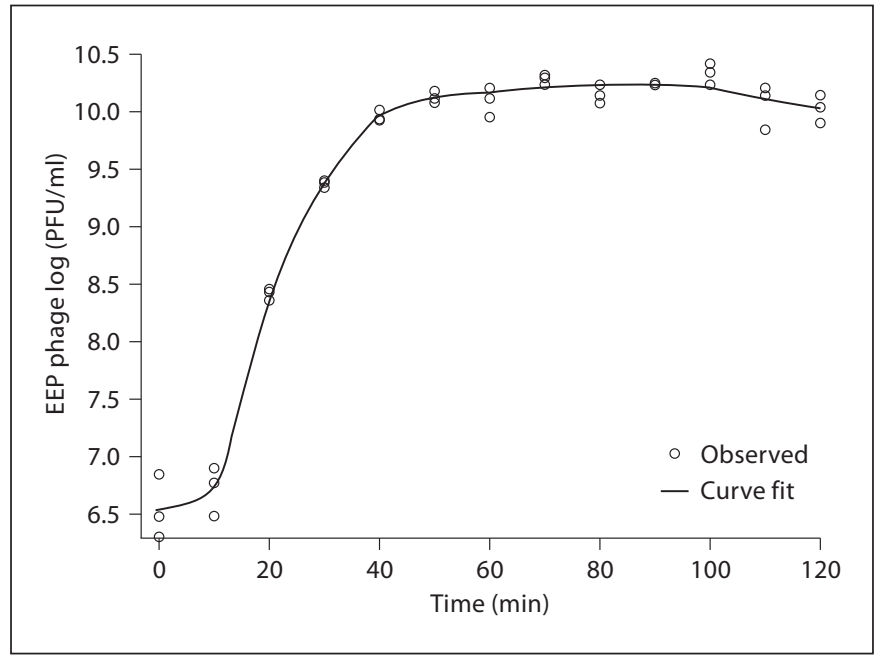

Fig. 2. One-step growth curve of EEP on BL21 (DE3). Experiments were repeated three times with duplicate samples.

Table 1. Susceptibility of different bacterial strains to EEP

\begin{tabular}{|c|c|c|c|}
\hline \multicolumn{2}{|l|}{ Bacterial strains } & \multirow{2}{*}{$\begin{array}{l}\text { Source } \\
\text { derivative of E. coli B strain with DE3 }\end{array}$} & \multirow{2}{*}{$\begin{array}{l}\text { Susceptibility } \\
+\end{array}$} \\
\hline Engineered & BL21 (DE3) & & \\
\hline E. coli strains & $\mathrm{DH} 10 \mathrm{~B}$ & derivative of E. coli MC1061 strain, an E. coli $\mathrm{K}-12$ strain & + \\
\hline & $\mathrm{DH} 5 \alpha$ & derivative of E. coli Hoffman-Berling 1100 strain, an E. coli $\mathrm{K}-12$ strain & + \\
\hline & JM109 & derivative of E. coli Hoffman-Berling 1100 strain, an E. coli $\mathrm{K}-12$ strain & + \\
\hline & M15 (PREP4) & derivative of E. coli K-12 strain & + \\
\hline & Rosetta (DE3) & derivative of E. coli B strain with DE3 & + \\
\hline & Rosetta-gami (DE3) & derivative of E. coli $\mathrm{K}-12$ strain with DE3 & + \\
\hline & S17-1 & derivative of E. coli K-12 strain & + \\
\hline & S17-1 $\lambda$ pir $^{+}$ & derivative of $E$. coli $\mathrm{K}-12$ strain & + \\
\hline & TOP10 & derivative of E. coli MC1061 strain, an E. coli K-12 strain & + \\
\hline ATCC E. coli strain & ATCC 35218 & commercial strain & - \\
\hline
\end{tabular}

Nucleotide Sequence Accession Number

The genomic sequence of EEP has been deposited in GenBank with the accession No. FJ750948 (Enterobacteria phage SSL2009a, NC_012223).

\section{Results}

\section{Morphological Features of EEP}

When EEP was grown on agar plates with BL21 (DE3), round, clear phage plaques $1-3 \mathrm{~mm}$ in diameter were seen, showing the characteristics of virulent bacteriophages. Electron microscopy showed that EEP virons have icosahedral heads $62 \pm 5 \mathrm{~nm}$ in diameter and long, flexible tails $138 \pm 16 \mathrm{~nm}$ in length (fig. 1).

\section{Physiological Features of EEP}

One-Step Growth Curve. The one-step growth curve of EEP was measured on engineered E. coli strain BL21 (DE3). As shown in figure 2, latent and burst periods of 10-15 and 30-40 min, respectively, were observed, indicating that only a short time was needed for EEP to adapt to a new environment. The burst size was estimated at $375 \pm 43 \mathrm{PFU}$ per infected cell. 


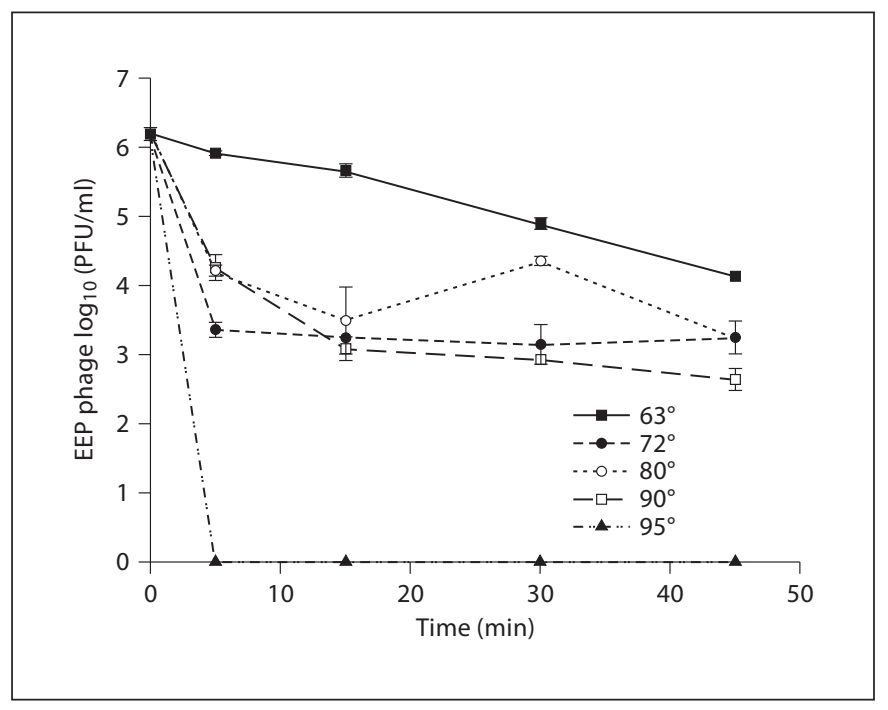

Fig. 3. Tolerance of EEP to thermal treatment (mean of 3 determinations).

Host Range. As shown in table 1, EEP was able to infect all the tested engineered $E$. coli strains, revealing a potent lytic capability for engineered $E$. coli, but was unable to lyse the ATCC 35218 E. coli strain.

Phage Stability. EEP is relatively resistant to thermal treatment (fig. 3). Heating to $63,72,80$ or $90^{\circ}$ was unable to completely inactivate high-titer phage suspensions, even after $45 \mathrm{~min}$. At $95^{\circ}$, the phage titers were reduced by $6 \log _{10}$ after only $5 \mathrm{~min}$. Ethanol is a widely used disinfectant. When phage EEP suspensions were treated with ethanol (fig. 4), phage titers were slightly decreased in the presence of ethanol $(25,50$ and $75 \%, v / v)$, and $>100$ viable phages per milliliter were detected after treatment with absolute alcohol $(100 \%, \mathrm{v} / \mathrm{v})$ for $45 \mathrm{~min}$. The effect of $\mathrm{pH}$ on EEP viability is summarized in figure 5. EEP was able to maintain its infectivity when incubated at $37^{\circ}$ in a $\mathrm{pH}$ range between 5 and 11 , but no phages could be detected after incubation at $\mathrm{pH} 2-3$ for $30 \mathrm{~min}$ or at $\mathrm{pH} 4$ for $60 \mathrm{~min}(<10 \mathrm{PFU} / \mathrm{ml})$.

\section{Genomic Features of EEP}

General Features of the EEP Genome. Whole-genome sequencing revealed that the double-stranded genomic DNA (dsDNA) of EEP consisted of 39,792 bp with a nucleotide composition of A (21.34\%), G (26.56\%), T (23.93\%) and C (28.16\%). It had an average GC content of $54.72 \%$, which is slightly higher than that of $E$. coli (50.8\%) [18]. A total of 223 ORFs $>100$ bp were predict-

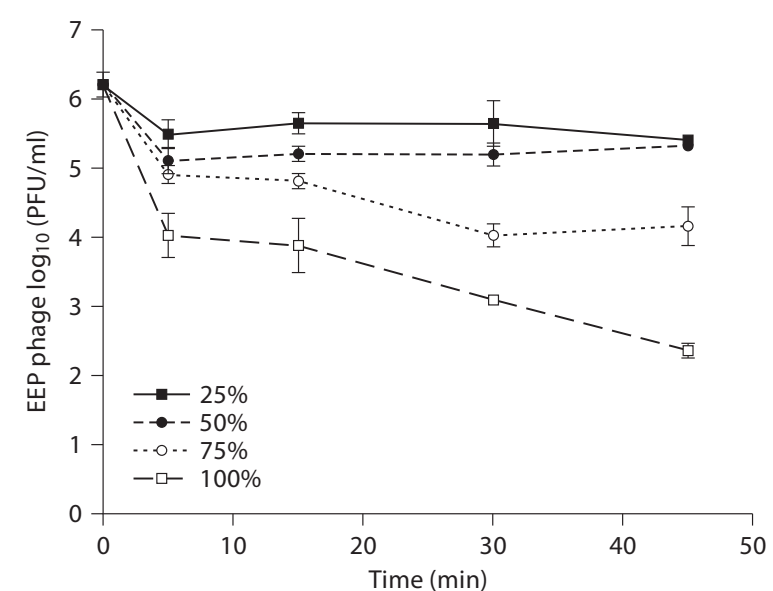

Fig. 4. Tolerance of EEP to ethanol (mean of 3 determinations).

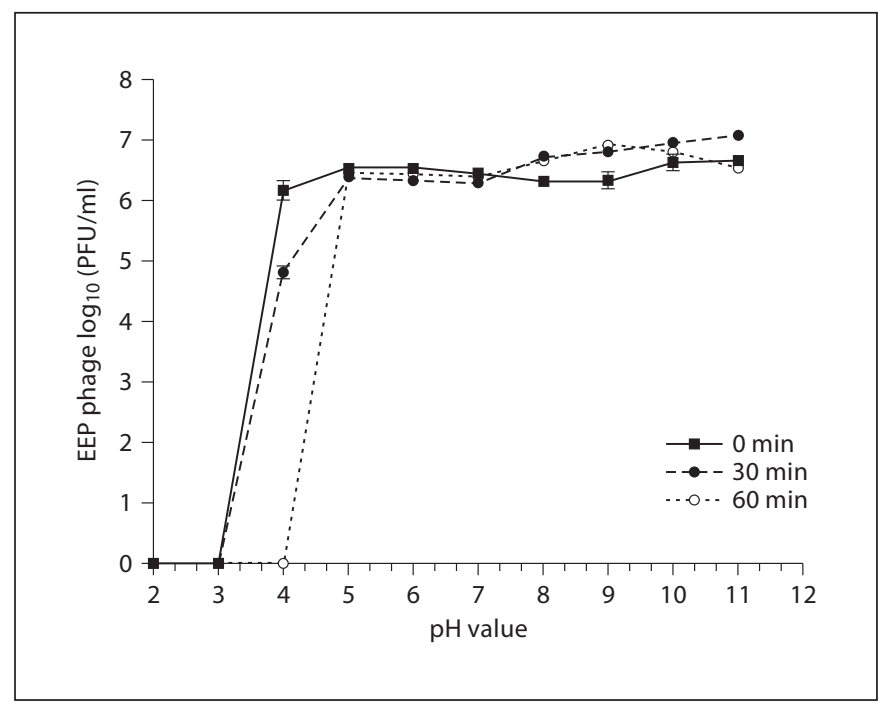

Fig. 5. Tolerance of EEP to $\mathrm{pH}$ variation (mean of 3 determinations).

ed from the EEP genome sequence using the software ORF Finder, among which 52 ORFs were identified as coding sequences (CDS). The average length of a gene was about $707 \mathrm{bp}$. We estimated that $92.34 \%$ of the whole sequence was involved in encoding proteins. Bacteriophages use their genetic sequence more efficiently and 
Table 2. The genes of EEP with predicated function

\begin{tabular}{|c|c|c|c|c|c|c|}
\hline $\begin{array}{l}\text { Coding } \\
\text { ORFs }\end{array}$ & Strand & & $\begin{array}{l}\text { Length } \\
\text { aa }\end{array}$ & $\begin{array}{l}\text { Mass } \\
\mathrm{kDa}\end{array}$ & Predicated function & $\begin{array}{l}\mathrm{E} \\
\text { value }\end{array}$ \\
\hline 1 & - & $149-844$ & 231 & 26.46 & $\begin{array}{l}\text { phage-related hypothetical protein of Enterobacteria phage phil } \\
\text { p189 }\end{array}$ & $1 e-77$ \\
\hline 2 & - & $841-2,265$ & 474 & 53.47 & phage-encoded associated helicase of Salmonella phage SETP3 & $2 \mathrm{e}-170$ \\
\hline 3 & - & $2,270-2,494$ & 74 & 8.68 & unknown gene & \\
\hline 4 & - & $2,532-2,705$ & 57 & 6.70 & unknown gene & \\
\hline 5 & - & $2,746-3,024$ & 92 & 10.27 & phage-related hypothetical protein of Salmonella phage KS7 & $2 \mathrm{e}-17$ \\
\hline 6 & - & $3,021-3,212$ & 63 & 6.92 & phage-related hypothetical protein of phage BP-4795 & $3 e-16$ \\
\hline 7 & - & $3,217-5,508$ & 763 & 86.26 & phage-related DNA polymerase I of Salmonella phage SETP3 & $2 \mathrm{e}-174$ \\
\hline 8 & - & $5,505-5,675$ & 56 & 6.21 & unknown gene & \\
\hline 9 & - & $5,735-6,529$ & 264 & 30.55 & phage-related hypothetical protein of Salmonella phage SETP3 & $3 e-28$ \\
\hline 10 & - & $6,605-6,847$ & 80 & 9.23 & unknown gene & \\
\hline 11 & - & $6,840-8,270$ & 476 & 52.42 & phage-related hypothetical protein of Salmonella phage SETP3 & $3 e-111$ \\
\hline 12 & - & $8,270-8,458$ & 62 & 7.21 & unknown gene & \\
\hline 13 & - & $8,459-8,710$ & 83 & 9.95 & unknown gene & \\
\hline 14 & - & $8,759-9,301$ & 180 & 19.77 & unknown gene & \\
\hline 15 & + & $9,702-10,031$ & 109 & 12.42 & unknown gene & \\
\hline 16 & + & $10,042-12,306$ & 754 & 82.81 & $\begin{array}{l}\text { putative phage replicative helicase/primase of } \\
\text { Burkholderia pseudomallei } \mathrm{BCC} 215\end{array}$ & $4 e-10$ \\
\hline 17 & + & $12,604-12,723$ & 39 & 4.34 & unknown gene & \\
\hline 18 & + & $12,777-12,995$ & 72 & 7.92 & $\begin{array}{l}\text { phage superinfection exclusion protein (COR-like protein) of } \\
\text { Enterobacteria phage N15 }\end{array}$ & $2 \mathrm{e}-08$ \\
\hline 19 & - & $13,012-13,683$ & 223 & 23.20 & phage-related hypothetical protein of Enterobacteria phage N15 & $5 e-54$ \\
\hline 20 & - & $13,686-13,988$ & 100 & 10.17 & phage-related hypothetical protein of Enterobacteria phage HK022 & $9 e-38$ \\
\hline 21 & - & $14,026-17,445$ & 1,139 & 125.74 & $\begin{array}{l}\text { putative phage tail fiber protein of Enterobacteria phage HK97, } \\
\text { N15, T1, etc. }\end{array}$ & 0.0 \\
\hline 22 & - & $17,442-18,059$ & 205 & 21.31 & $\begin{array}{l}\text { putative phage tail assembly protein I of Yersinia pestis CO92, } \\
\text { KIM, etc. }\end{array}$ & $3 e-37$ \\
\hline 23 & - & $18,050-18,790$ & 246 & 27.58 & $\begin{array}{l}\text { putative phage minor tail protein of Yersinia enterocolitica subsp. } \\
\text { enterocolitica } 8081\end{array}$ & $4 e-44$ \\
\hline 24 & - & $18,793-19,581$ & 262 & 28.78 & phage minor tail protein L of Y. pestis KIM, Angola, etc. & $2 \mathrm{e}-46$ \\
\hline 25 & - & $19,578-20,177$ & 199 & 21.51 & putative minor tail protein of Enterobacteria phage T1 & $1 e-06$ \\
\hline 26 & - & $20,214-22,853$ & 879 & 93.15 & $\begin{array}{l}\text { putative bacteriophage tail tape measure protein of } \\
\text { Shigella flexneri } 2 \text { a str. } 301\end{array}$ & $2 \mathrm{e}-54$ \\
\hline 27 & - & $23,238-23,333$ & 31 & 3.62 & unknown gene & \\
\hline 28 & - & $23,552-23,956$ & 134 & 15.53 & $\begin{array}{l}\text { phage-related hypothetical protein of Y. enterocolitica subsp. en- } \\
\text { terocolitica } 8081\end{array}$ & $4 e-13$ \\
\hline 29 & - & $23,985-24,710$ & 241 & 25.65 & putative major tail protein of Enterobacteria phage T1 & $2 \mathrm{e}-26$ \\
\hline 30 & - & $24,772-25,194$ & 140 & 15.15 & unknown gene & \\
\hline 31 & - & $25,194-25,787$ & 197 & 21.95 & phage-related hypothetical protein of Proteus mirabilis HI4320 & $2 e-28$ \\
\hline 32 & - & $25,789-26,148$ & 119 & 13.14 & conserved phage structural protein of $P$. mirabilis HI4320 & $8 \mathrm{e}-11$ \\
\hline 33 & - & $26,247-26,777$ & 176 & 18.93 & unknown gene & \\
\hline 34 & - & $26,806-27,789$ & 327 & 34.33 & conserved phage structural protein of Pseudomonas phage 73 & $2 \mathrm{e}-17$ \\
\hline 35 & - & $27,791-27,904$ & 37 & 4.13 & unknown gene & \\
\hline 36 & - & $28,002-28,703$ & 233 & 25.35 & phage-related hypothetical protein of Pseudomonas phage 73 & $3 e-19$ \\
\hline 37 & + & $28,843-29,172$ & 109 & 11.59 & unknown gene & \\
\hline 38 & + & $29,212-29,790$ & 192 & 21.87 & unknown gene & \\
\hline 39 & + & $29,804-29,968$ & 54 & 6.03 & lysozyme & $4 e-18$ \\
\hline
\end{tabular}


Table 2 (continued)

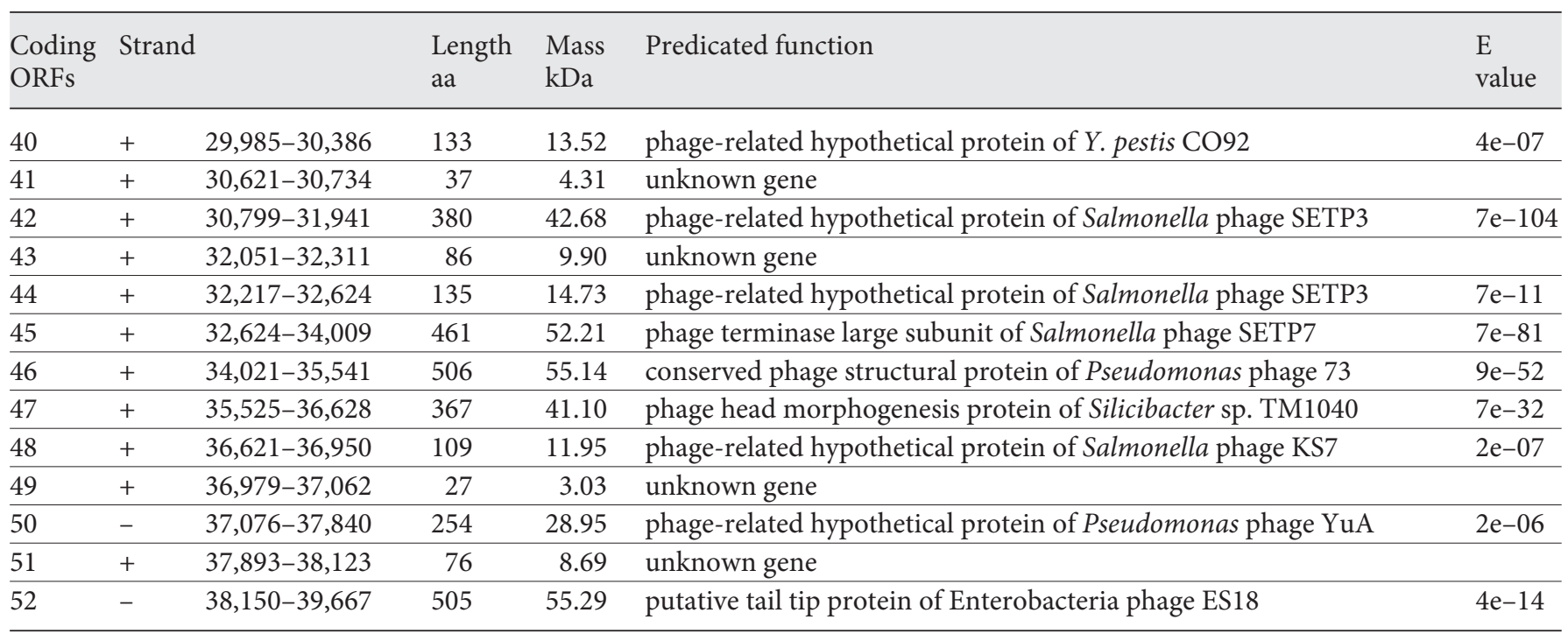

Table 3. The N-terminal amino acid sequencing results of some structural EEP proteins

\begin{tabular}{ll}
\hline Protein bands & Sequence of the N-terminal 5 amino acids \\
\hline $123.5 \mathrm{kDa}$ & Met-Ile-Thr-Thr-Tyr (MITTY) \\
$90.2 \mathrm{kDa}$ & Ala-Asp-Gln-Ala-Ala (ADQAA) \\
$65.5 \mathrm{kDa}$ & Thr-Val-Asn-Val-Asp (TVNVD) \\
$40.5 \mathrm{kDa}$ & Ser-Leu-Thr-Val-Phe (SLTVF) \\
$26.3 \mathrm{kDa}$ & Gly-Tyr-Gln-Leu-Pro (GYQLP) \\
$15.6 \mathrm{kDa}$ & Met-Leu-Asp-Ser-Ile (MLDSI) \\
\hline
\end{tabular}

economically than host bacteria and higher organisms $[17,18]$.

Predicted CDS and Their Features. When BLASTN analysis of the entire EEP genomic sequence was conducted, no homologous sequences $>100$ bp were found in the public databases, indicating that the EEP genome is distinct from all previously sequenced phage genomes. The 52 potential CDS of the EEP genome were searched individually using BLASTP at the NCBI database. Positions, sizes and putative functions of the proteins as well as similarities to other proteins are listed in table 2 and figure 6. Among these potential CDS, 18 ORFs (34.6\%) identified homologous genes coding for phage structural proteins or replication-related enzymes. The remaining ORFs are functionally unknown, 19 ORFs (36.5\%) code for proteins with a high degree of homology to phage- related hypothetical proteins, and 15 ORFs (28.8\%) code for unique products with little or no homology to proteins from the database.

Structural Proteins of EEP and Their N-Terminal Sequencing. In order to analyze the structural proteins of EEP, purified phage particles were treated by boiling with sample buffer, and then separated by SDS-PAGE. At least eight distinct protein bands, with molecular weights ranging from 16 to $124 \mathrm{kDa}$, were visualized in the gels (fig. 7). The most abundant was a $40.5-\mathrm{kDa}$ protein, most likely to be the major coat protein of EEP, while a 26.3$\mathrm{kDa}$ protein was identified as the secondary coat protein. To determine the coding ORF of every structural protein, all the protein bands in the SDS-PAGE gel were transferred onto polyvinylidene fluoride membranes and their five $\mathrm{N}$-terminal amino acids were sequenced. The results of six bands (123.5, 90.2, 65.5, 40.5, 26.3 and $15.6 \mathrm{kDa})$ with large enough protein samples are listed in table 3.

\section{Discussion}

Bacteriophages are ubiquitous in nature. According to morphology and nucleic acid properties, phages may be divided into 21 morphotypes which correspond to 13 phage families. About $96 \%$ of phages investigated in the last 50 years are tailed phages belonging to the Siphoviridae, Myoviridae or Podoviridae families [19, 20]. Siphoviridae (isometric head and non-contractile tail) is by far 


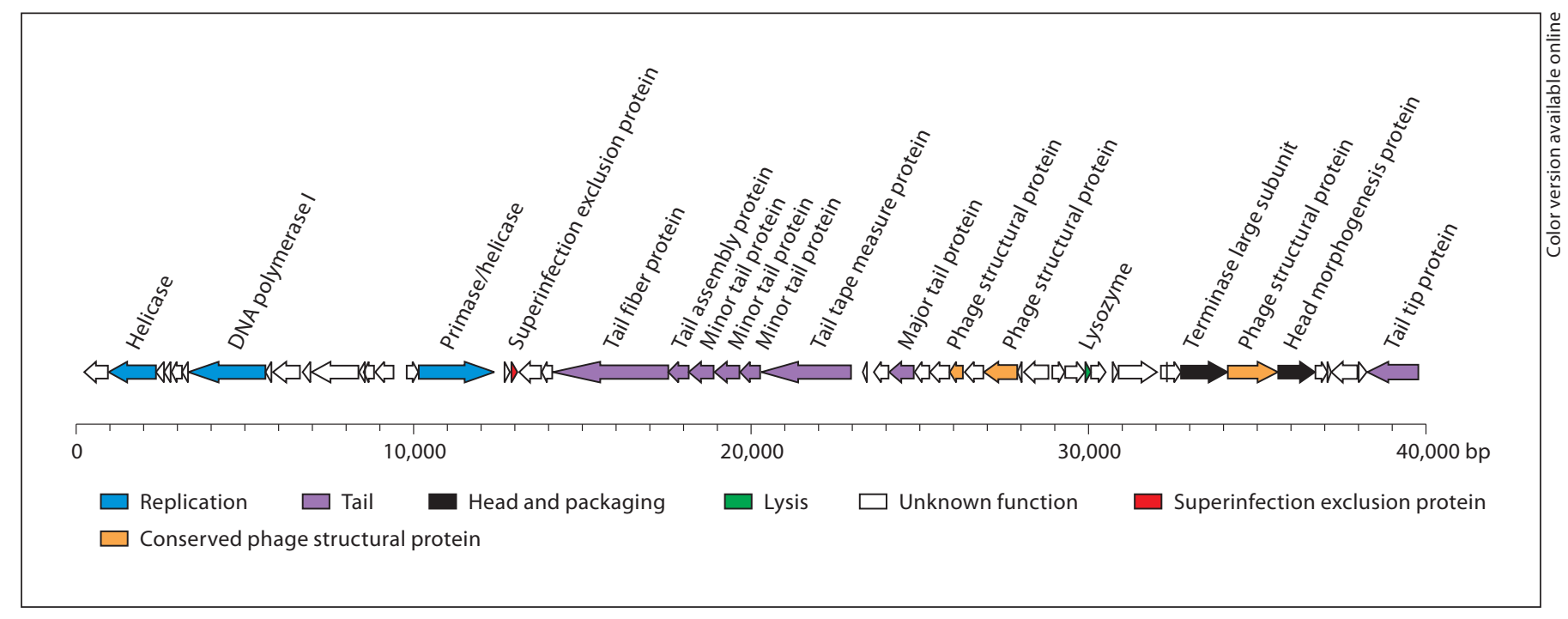

Fig. 6. The organization of predicted genes of EEP.

the most frequent phage group (61.7\%) [21, 22]. EEP, which has an icosahedral head and a long, flexible and non-contractile tail, should be classified as a member of the Siphoviridae family.

It is known that bacteriophages infect host cells with very high specificity. Phage EEP was isolated from an engineered $E$. coli culture, and we therefore determined which engineered E. coli strains were sensitive to EEP. Ten engineered E. coli strains that are commonly used in bioprocessing and molecular biological researches were tested for their susceptibilities to phage EEP. Results indicated that all the tested engineered $E$. coli strains were sensitive to EEP, suggesting that EEP has strong lytic ability for engineered E. coli strains and could potentially pose a significant threat to biomanufacturing processes that use engineered $E$. coli as the production strain. The most likely explanation for the broad host range of EEP is that some common proteins on the cell surfaces of these host strains are used by EEP as recognition receptor. Among these sensitive engineered E. coli strains, BL21 (DE3) and Rosetta (DE3) are derived from E. coli B strain, while DH10B, DH5 $\alpha$, JM109, M15, Rosetta-gami, TOP10, S17-1 and S17-1 $\lambda$ pir $^{+}$are from E. coli K-12 strain. All these host strains belong to E. coli species of the Escherichia genus. Therefore, it is not hard to understand that they share common adsorption receptors to phage EEP. Actually, relatively broad host ranges of bacteriophages are also found in other works [13, 23-25].

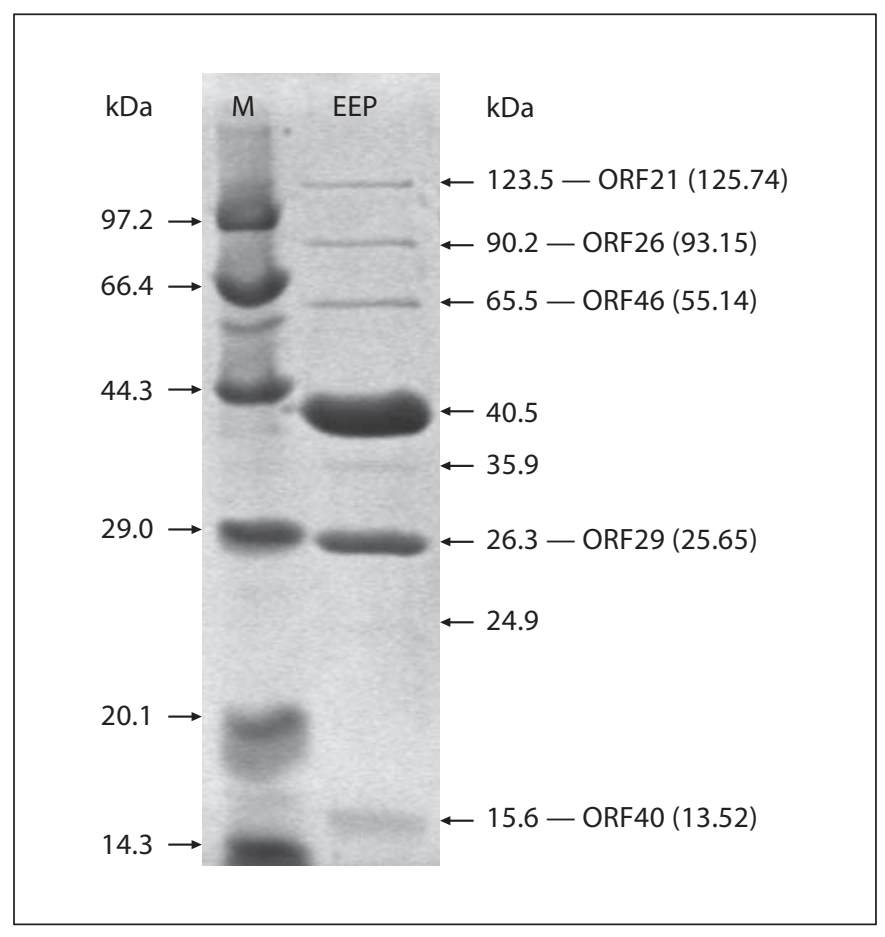

Fig. 7. EEP proteins separated by SDS-PAGE and their corresponding putative ORFs. Purified EEP particles were lysed in sample buffer and the proteins resolved on a 12\% SDS-PAGE gel, followed by Coomassie staining, which revealed at least 8 bands. 
Different physicochemical parameters, such as heat, biocide and $\mathrm{pH}$ changes of the environment, can affect the viability of phages. Our studies indicated that EEP was able to survive high thermal treatments. The results of thermal tolerance of EEP were similar to those of the Lactobacillus paracasei phage (MLC-A), which also demonstrated high resistance to temperatures $>72^{\circ}$ and was completely inactivated when heated at $90^{\circ}$ for $2 \min$ [26]. Most bacteriophages are sensitive to thermal treatment: about $76 \%$ of phage V-45, a bacteriophage of Vibrio fetus, were inactivated by incubation at $20^{\circ}$ for $1 \mathrm{~h}$. Proportionately greater inactivation was observed from 30 to $50^{\circ}$, and all phage activity was destroyed after $10 \mathrm{~min}$ at $60^{\circ}$ [27]. Bacteriophages resistant to high temperatures pose a greater threat to industrial fermentation processes because they are able to survive thermal treatments and multiply at relatively high temperatures.

Ethanol is widely used in disinfection, but the most effective concentration of ethanol $(75 \%, v / v)$ and even dehydrated alcohol were not able to completely inactivate EEP. The failure of ethanol also suggests the absence of a lipid envelope outside the capsid of the phage.

The data of $\mathrm{pH}$ resistance test suggest that EEP is sensitive to acid conditions but tolerant to alkaline conditions. Musarrat and Ahmad [28] reported that bacteriophage $\lambda$-E. coli complexes exhibited remarkable sensitivity to alkaline $\mathrm{pH} 10.0$ at $37^{\circ}$. Studies of five lactic Streptococcus phage strains showed that the proliferation of phage F55 was reduced at pH 7.5, while F24 caused mass lysis of susceptible cells at the same $\mathrm{pH}$ level, and strains F56 and F43 were able to proliferate at $\mathrm{pH} 8.4$ and 8.6, respectively [29]. Compared to these bacteriophages, EEP is more tolerant to alkaline conditions.

We determined the nucleotide sequence of the entire EEP genome. Putative ORFs $(n=52)$ were identified as CDS on the EEP genome, and 18 ORFs code for proteins with a high degree of homology to known phage proteins. Generally, phage genomes are organized in modular structures, with each module containing clusters of genes with specific functions [30]. The $18 \mathrm{ORF}$ of the EEP genome with predicted function are organized into three modules containing gene clusters for DNA replication and DNA packaging, structural proteins and host cell lysis.

ORFs coding for putative phage replicative helicase/ primase (ORF2/ORF16), phage-related DNA polymerase I (ORF7) and phage terminase (ORF45) are identified as members of the DNA replication and packaging module of the EEP genome. Primase/helicase is known to be an enzyme with dual activities. During DNA replication, duplex DNA is initially unwound by the helicase in the presence of ATP, and the primase then catalyses the formation of a short RNA segment called a primer, and the DNA polymerase finally catalyses DNA synthesis [31,32]. The protein coded by ORF45 showed a high sequence similarity to the terminases of the Salmonella phages (SETP5, SETP7 and SETP12), with an E value of 7e-81, strongly suggesting that ORF45 is the coding gene for the EEP terminase. The terminase complex, comprising one small and one large subunit [33], is a key component of the dsDNA packaging machine for packing replicated genomic DNA into preassembled empty capsid shells using its endonuclease and ATPase activities [34-36]. The coding product of ORF45 corresponded to the large subunit of EEP terminase. Many of the ORFs in this module might encode unique products which shared no homologies with proteins present in the microbial database, and we were not able to predict their function based on BLAST analysis. However, the known ORFs contained in EEP DNA replication and packaging modules show a high sequence similarity to the same proteins of Salmonella phages, e.g. Salmonella phage SETP3, KS7 and KS73.

Analogous to other dsDNA bacteriophages, the structural module in phage EEP is located next to the DNA replication module [37]. Some structural proteins of phage EEP were examined by SDS-PAGE (fig. 7), and Nterminal sequencing of 6 structural proteins was performed (table 3). Compared with the protein sequence of the 52 coding ORFs, only ORF21 coded a product ( 125.7 $\mathrm{kDa}$ ) close to $123.5 \mathrm{kDa}$. The $\mathrm{N}$-terminal sequences (MetIle-Thr-Thr-Tyr) for the $123.5-\mathrm{kDa}$ protein in SDS-PAGE (fig. 7) matched with the predicted $\mathrm{N}$-terminal sequence of ORF21, which showed sequence similarity with a tail fiber protein of enterobacterium phage HK97. The N-terminal sequences of the 90.2 - and $26.3-\mathrm{kDa}$ proteins isolated from SDS-PAGE were identified as Ala-Asp-GlnAla-Ala and Gly-Tyr-Gln-Leu-Pro, and matched with the predicted amino acids of ORF26 and ORF29, respectively. ORF26 and ORF29 shared high sequence similarity with the phage tail tape measure protein of Shigella flexneri 2a strain 301 and a major tail protein of enterobacterium phage T1, respectively. Similarly, the 65.5- and $15.6-\mathrm{kDa}$ structural proteins were also determined to be coded by ORF46 and ORF40. The inability to identify the coding gene for the major EEP coat protein (the 40.5$\mathrm{kDa}$ protein from SDS-PAGE) may possibly be explained by the inability to predict the corresponding ORF using bioinformatics. Otherwise, ORFs coding for putative phage tail proteins (ORF22, ORF23, ORF24, ORF25 and ORF52), phage head morphogenesis protein (ORF47) and 
conserved phage structural proteins (ORF32 and ORF34) were also classified into the structural module of the EEP genome. Interestingly, the nucleotide sequences of ORFs in the EEP structural module were found to share a high degree of homology with the sequence of structural proteins of enterobacterial phages, e.g. N15, HK022, HK97, TLS and T1.

ORF39 belongs to the lysis module of phage EEP. Lysozyme is one of the most important functional proteins for bacteriophages and has the ability to hydrolyze the $\beta 1-\beta 4$ linkage of the peptidoglycan backbone of the bacterial cell wall [38]. The product coded by ORF39 showed homology with lysozyme with a score of 93.6, and was thus identified as lysozyme.

The product coded by ORF18 was homologous to the superinfection exclusion COR-like protein of the enterobacterial phage N15, with an E value of $2 \mathrm{e}-08$. This protein acts to prevent EEP from being substituted by other superinfecting phages.
In summary, we experimentally identified the coding genes for 5 constituent proteins, which, together with the 18 known-function genes predicted by bioinformatics searching, means that 23 genes of the EEP genome were functionally delineated in the present study.

The elucidation of the physicochemical and genomic properties of this novel coliphage, which has strong lytic ability to engineered E. coli strains, may help to elucidate phage diversity and to establish effective phage control strategies in fermentation industries and laboratory environments.

\section{Acknowledgment}

This work was supported by the National Natural Science Foundation of China (30700711).

\section{References}

1 Lima-Mendez G, Toussaint A, Leplae R: Analysis of the phage sequence space: the benefit of structured information. Virology 2007;365:241-249.

$\checkmark 2$ Boyd EF, Brussow H: Common themes among bacteriophage-encoded virulence factors and diversity among the bacteriophages involved. Trends Microbiol 2002;10: 521-529.

$\checkmark 3$ Frost LS, Leplae R, Summers AO, Toussaint A: Mobile genetic elements: the agents of open source evolution. Nat Rev Microbiol 2005;3:722-732.

4 Smets BF, Barkay T: Horizontal gene transfer: perspectives at a crossroads of scientific disciplines. Nat Rev Mi Opin Microbiol 2005;8:459-465.

$\checkmark 5$ Waldor MK, Friedman DI: Phage regulatory circuits and virulence gene expression. Curr Opin Microbiol 2005;8:459-465.

$\checkmark 6$ Hendrix RW: Bacteriophage genomics. Curr Opin Microbiol 2003;6:506-511.

-7 Ackermann HW: 5500 phages examined in the electron microscope. Arch Virol 2007; 152:227-243.

8 Iida Y, Matsuda Y, Saito R, Nakasato M, Nonomura T, Kakutani K, Tosa Y, Mayama $S$, et al: Efficient release of overproduced gene products from Escherichia coli BL21 (DE3) by lytic infection with newly isolated bacteriophages. Biosci Biotechnol Biochem 2003;67:198-202

9 Govind R, Fralick JA, Rolfe RD: Genomic organization and molecular characterization of Clostridium difficile bacteriophage ФCD119. J Bacteriol 2006;188:2568-2577.
10 Casas V, Rohwer F: Phage metagenomics. Methods Enzymol 2007;421:259-268.

-11 Shelton CB, Crosslin DR, Casey JL, Ng S, Temple LM, Orndorff PE: Discovery, purification, and characterization of a temperate transducing bacteriophage for Bordetella avium. J Bacteriol 2000;182:6130-6136.

12 Lu Z, Breidt FJ, Fleming HP, Altermann E, Klaenhammer TR: Isolation and characterization of a Lactobacillus plantarum bacteriophage, $\Phi J \mathrm{~L}-1$, from a cucumber fermentation. Int J Food Microbiol 2003;84:225-235.

13 Wu LT, Chang SY, Yen MR, Yang TC, Tseng YH: Characterization of extended-hostrange pseudo-T-even bacteriophage Kpp95 isolated on Klebsiella pneumoniae. Appl Environ Microbiol 2007;73:2532-2540.

14 Capra ML, Quiberoni A, Reinheimer JA: Thermal and chemical resistance of Lactoba cillus casei and Lactobacillus paracasei bacteriophages. Lett Appl Microbiol 2004;38: 499-504

15 Dong $\mathrm{H}$, Lin W, Zhang CK, Xiong H, Fu G Jin WR, Chen R, Chen Z, et al: Genomic sequence and expression analyses of human chromatin assembly factor 1 p150 gene. Gene 2001;264:187-196.

16 Fleischmann RD, Adams MD, White O, Clayton RA, Kirkness EF, Kerlavage AR, Bult CJ, Tomb JF, et al: Whole genome random sequencing and assembly of Haemophilus influenzae Rd. Science 1995;269:496512 .
17 Istrail S, Sutton GG, Florea L, Halpern AL, Mobarry CM, Lippert R, Walenz B, Shatkay $\mathrm{H}$, et al: Whole-genome shotgun assembly and comparison of human genome assemblies. Proc Natl Acad Sci USA 2004;101: 1916-1921.

18 Blattner FR, Plunkett GIII, Bloch CA, Perna NT, Burland V, Riley M, Collado-Vides J, Glasner JD, et al: The complete genome sequence of Escherichia coli K-12. Science 1997; 277:1453-1462.

19 Ackermann HW, DuBow MS: Viruses of Prokaryotes, vol II: Natural Groups of Bacteriophages. Boca Raton, CRC Press, 1987, pp 1-54, 171-218.

20 Ackermann HW: Frequency of morphological phage descriptions in the year 2000. Arch Virol 2001;146:843-857.

21 Sechaud L, Cluzel PJ, Rousseau M, Baumgartner A, Accolas JP: Bacteriophage of lactobacilli. Biochimie 1988;70:401-410.

$>22$ Ackermann HW: Tailed bacteriophage: the order caudovirales. Adv Virus Res 1998;51: 135-201.

-23 Ruokoranta TM, Grahn AM, Ravantti JJ, Poranen MM, Bamford DH: Complete genome sequence of the broad host range singlestranded RNA phage PRR1 places it in the Levivirus genus with characteristics shared with Alloleviviruses. J Virol 2006;80:93269330

24 Majumdar S, Barman S, Das J: Phage phi 92: a new choleraphage infecting Vibrio cholerae cells belonging to serovars 01 and non-01. Intervirology 1993;36:237-244. 
-25 Synnott AJ, Kuang Y, Kurimoto M, Yamamichi K, Iwano H, Tanji Y: Isolation from sewage influent and characterization of novel Staphylococcus aureus bacteriophages with wide host ranges and potent lytic capabilities. Appl Environ Microbiol 2009;75: 4483-4490.

-26 Capra ML, Del L, Quiberoni A, Ackermann HW, Moineau S, Reinheimer JA: Characterization of a new virulent phage (MLC-A) of Lactobacillus paracasei. J Dairy Sci 2006;89: 2414-2423.

-27 Bryner JH, Ritchie AE, Foley JW, Berman DT: Isolation and characterization of a bacteriophage for Vibrio fetus. J Virol 1970;6: 94-99.

-28 Musarrat J, Ahmad M: Damage and mutagenesis of bacteriophage lambda induced by high pH. Mutagenesis 1991;6:207-211.
29 Overcast WW, Nelson FE, Parmelee CE: Influence of $\mathrm{pH}$ on proliferation of lactic Streptococcus bacteriophage. J Bacteriol 1951;61: 87-95.

30 Brussow H, Hendrix RW: Phage genomics: small is beautiful. Cell 2002;108:13-16.

-31 Lee J, Chastain PD, Griffith JD, Richardson CC: Lagging strand synthesis in coordinated DNA synthesis by bacteriophage $\mathrm{t} 7$ replication proteins. J Mol Biol 2002;316:19-34.

32 VanLoock MS, Chen YJ, Yu X, Patel SS, Egelman EH: The primase active site is on the outside of the hexameric bacteriophage T7 gene 4 helicase-primase ring. J Mol Biol 2001; 311:951-956.

33 Kanamaru S, Kondabagil K, Rossmann MG, Rao VB: The functional domains of bacteriophage t4 terminase. J Biol Chem 2004;279: 40795-40801.

-34 Alam TI, Rao VB: The ATPase domain of the large terminase protein, gp17, from bacteriophage T4 binds DNA: implications to the DNA packaging mechanism. J Mol Biol 2008;376:1272-1281.
35 Maluf NK, Gaussier H, Bogner E, Feiss M, Catalano CE: Assembly of bacteriophage lambda terminase into a viral DNA maturation and packaging machine. Biochemistry 2006;45:15259-15268.

36 Ponchon L, Boulanger P, Labesse G, Letellier $\mathrm{L}$ : The endonuclease domain of bacteriophage terminases belongs to the resolvase/ integrase/ribonuclease $\mathrm{H}$ superfamily: a bioinformatics analysis validated by a functional study on bacteriophage T5. J Biol Chem 2006;281:5829-5836.

37 Zimmer M, Scherer S, Loessner MJ: Genomic analysis of Clostridium perfringens bacteriophage $\phi 3626$, which integrates into guaA and possibly affects sporulation. J Bacteriol 2002;184:4359-4368.

38 Rossmann MG, Mesyanzhinov VV, Arisaka F, Leiman PG: The bacteriophage T4 DNA injection machine. Curr Opin Struct Biol 2004;14:171-180. 